\title{
Treatment of Students' English Oral Errors at Shambu Preparatory School: Grade 11 in Focus
}

\author{
Leta Regasa and Tamiru Olana*
}

Institute of Languages Study and Journalism, Wollega University, Post Box No: 395, Nekemte, Ethiopia

\begin{tabular}{|c|c|}
\hline \multirow{14}{*}{$\begin{array}{l}\text { Abstract } \\
\text { The study was conducted in an attempt to investigate teachers' treatment of students' oral } \\
\text { errors in EFL classes at Shambu Preparatory School. Descriptive survey design was used to } \\
\text { investigate the major identified students' oral errors, to find out the types of oral error } \\
\text { treatments EFL teachers provide and to investigate the techniques they use to treat } \\
\text { students' oral errors. Interview and observation were used as instruments of data collection. } \\
\text { The participants of the study were two English language teachers of grade } 11 \text { who were } \\
\text { comprehensively selected to participate in interview and get their classes observed as well. } \\
\text { The results indicated that there were } 66 \text { oral errors made by students which were } \\
\text { categorized into } 10 \text { as pronunciation, tense, verb group, agreement, noun group, preposition, } \\
\text { word order, article, wrong numbers and adjectives. The findings also showed 13 types of oral } \\
\text { error treatments were made by the targeted teachers as provide, transfer, praise, } \\
\text { explanation, question, interruption, acceptance, repetition, use of blackboard, ignore, } \\
\text { negation and clues, prompt and criticism. Furthermore, it revealed that teachers used three } \\
\text { techniques of oral error treatments as Teacher correction, Self correction and peer correction } \\
\text { giving more room to teacher correction which is not pedagogically sound. Therefore, to } \\
\text { alleviate the students' linguistic problems, the targeted teachers are required to give } \\
\text { appropriate oral error treatments. Besides, it would be better if the teachers give students the } \\
\text { chance of self correction instead of playing the lion's role by themselves. }\end{array}$} & \\
\hline & Received : 10-12-2015 \\
\hline & evised : $\quad 24-02-2016$ \\
\hline & Accepted : 06-03-2016 \\
\hline & \\
\hline & \\
\hline & \\
\hline & nce \\
\hline & \\
\hline & \\
\hline & \\
\hline & \\
\hline & \\
\hline & \\
\hline
\end{tabular}

\section{INTRODUCTION}

In earlier times, errors were considered as wrong learning and were intolerable. Over the past fifty years, there has been a shift in pedagogical focus from preventing errors in learning a language. In the 1950s and 60 s during audiolingualism, language students had to repeat pattern drills and grammatical structures in order to avoid errors. However, in the late 1960s, language teaching became more humanistic and students were encouraged to learn by communicating in the target language. Subsequently, a more positive attitude towards oral errors has emerged. Now many scholars view errors as a natural and important part of learning because they yield information about learning a language.

Since the late 1960s, there has been a change of trend from audiogualism to transformational generative grammar, which made language teaching more humanistic and less mechanistic. This attitudinal change made foreign language teachers examine the learning style of their students and stress on the use of language for communication. Ur (2002) writes that more important than error free speech is the creation of an atmosphere in which students want to talk. This led to the positive perspective toward second language errors. As a result, many language educators proposed that foreign language teachers also should accept those errors as neutral phenomena integral to second language learning process.
They need to tolerate some students' errors. This is because students feel more confident about using the target language than all their errors corrected (Stern, 1992; Brown, 2000).

Errors provide feedback, tell the teacher something about the effectiveness of his teaching materials and techniques and show him what part of the syllabus has been followed, learned or taught and need further attention (Corder, 1974). They enable teachers to decide whether they must devote more time to the item has been working on. Errors provide information for designing remedial syllabus or a program for teaching (ibid).

Furthermore, Corder (1981) states two schools of thoughts in the field of methodology in respect to students' errors. The first one considers errors as signs of the present inadequacy of teaching techniques to be avoided. The second thought regards errors inevitable things to be dealt with technically. In general, there has been a shift in methodological and pedagogical focus from preventing errors to learning from errors since the time of audiolingualism. This can be shortly expressed in George (1972) as it is not worthy that at the beginning of the 60s the word error was associated with correction, but at the end with learning. 


\section{Leta Regasa and Tamiru Olana}

It was suggested that since the goal of instruction is to improve students' ability to monitor their own target language speech, the priority should be given to correct students' errors. Error treatment that encourages students' correction helps them make inferences and formulate concepts about the target language (Allwright and Bailey, 1991).

There have been studies conducted on oral feedback provision in the Ethiopian context. For example, Wondwosen (1992) studied about the classroom feedback behavior of teachers on oral errors. He aimed at finding out the amount of class time spent on feedback provision, types of feedback teachers use and whether regular patterns exist in the reaction in providing feedback. Teshome (1995) studied teachers' corrective treatment of students' oral errors and investigated that teachers' luck awareness about the important types of corrective techniques to be used. Sileshi (2008) also studied on oral corrective feedback and found out that teachers did not seem to have enough and appropriate information as to which corrective techniques were useful to improve students' oral proficiency. Tamiru and Zeleke (2015) investigate that let alone correcting students oral errors, EFL teachers themselves make many written and oral errors when they teach.

Although their areas of focus differ, the works of Teshome and Sileshi are more related to this topic than the other two. However, this one is different from the two in that it focuses on the major types of identified students' oral errors in the EFL classes, the types of oral error treatments EFL teachers provide and the techniques EFL teachers use to treat students' oral errors. Accordingly, the following research questions were considered in the study.

1. What are the major identified students' oral errors in EFL Classes?

2. What are the types of oral error treatments EFL teachers provide?

3. What techniques do EFL teachers use to treat students' oral errors?

\section{Mistakes vs. Errors}

To deal with students' errors and to analyze students language in proper perspective, it is crucial to make a distinction between mistakes and errors. According to Brown (1994), 'mistake' refers to performance error that is either a random guess or a slip in that it is failure to utilize a known system correctly. All people make mistakes, in both native and second language situations. Native speakers are normally capable of recognizing and correcting such lapses or mistakes, which are not the result of a deficiency in competence but the result of some sort of breakdown or imperfection in the process of producing speech. These hesitations, slip of tongue, random ungrammaticalities, and other performance lapses in native speaker's production also occur in the second language speech. Non-native speakers might also be capable of remedying some of the students' mistakes and when they fail to recognize their slips, a little help from teachers or others enable them to do self correction (Brown, 1994; Ferris, 2002).

However, Corder (1974) argues that mistakes were of no significance to the process of language since they did not reflect a defect in knowledge of the language.
Sci. Technol. Arts Res. J., Jan-March 2016, 5(1): 115-122

According to Edge (1989), all deviations from Standard English are not errors rather they are mistakes. A slip is a mistake which a student can self correct if it is pointed out by teacher, whereas an error cannot be corrected by the student, even if it is pointed out.

\section{The Concept of Feedback in the EFL Classroom}

The concept of error treatment has been a point of interest for both language teachers and researchers in relation to classroom interaction (Nuru, 2000) and there are terms like feedback, repair, correction and treatment which usually used in literature to serve similar concepts. Therefore, it is important to see these terms briefly. According to Chaudron (1988), feedback is an aspect of interaction in classroom with the widest scope which includes the notion of error correction and in which speakers drive from their listeners' information on the reception and comprehension of their messages in any communicative exchange. Makiano (1993) explains feedback as an error detection which is designed to promote correction by supplying students with information about the correctness of their language production. Conversely, Hilton (2007) argues that gaps in lexical and pronunciation knowledge hinder oral communication.

Vanlier (1995) tries to make a distinction between repairs and correction. He states repair as the generic term and that correction one type of repair namely the replacement of an error made by the speaker with the correct form. Treatment on the other hand, is used to any teacher behavior following an error that minimally attempts to inform students about the fact of error (Chaudron, 1986). According to Allwright and Bailey (1991), error correction and error treatment may be used interchangeably. However, still there is conceptual problem as the phrase error correction implies cure which in turn shows students being accurate after the treatment. Because of the close concepts of the terminologies mentioned, it is inevitable to come across them in this research work (Ancker, 2000). So it is not surprising if the researcher uses these terms in the subsequent parts.

\section{Oral Feedback}

Oral feedback is a natural part of verbal interaction between students and teachers, or students and students. It is mostly considered to happen between a teacher and a student, but researchers like Yang, Badger and $\mathrm{Yu}$ (2006) note that a great deal of verbal feedback also comes from peers. Hattie and Gan (2011) explain that oral feedback can be group-focused or more individualfocused feedback.

\section{Oral Feedback Provision Techniques}

The only dominant type of feedback for the production process of developed text cannot be teacher feedback. Students can also give feedback to each other, which is called peer feedback, peer review, peer response and peer evaluation (Hattie and Gan, 2011). Specifically, they define peer feedback as 'the learners' use of sources of information and interactions for each other in such a way that learners take on the responsibilities in commenting on each other's work. Peer feedback can contribute to peers' social relations, intellectual improvement, and progressing of creative and critical thinking (Damon and Phelps, 1989). Mittan (1989) and Damon and Phelps (1989) discuss the advantages of peer feedback regarding cognitive benefit in leading students to think rather than receive feedback from the teacher. Therefore, they 


\section{Leta Regasa and Tamiru Olana}

become aware that not only teacher is source of feedback but also students can provide feedback to each other.

Most of the time collective/group feedback happens when the teacher collects the most common mistakes and corrects them in class so as not to single out any individual student. For example, (Leki, 1990) states that even though feedback can be provided individually, it is more efficient if the whole class is involved so that students can learn from each other's mistakes. Students who get feedback only from their teacher see the teacher as a judge who critiques what they say.

\section{Treated and Untreated Feedback}

Teachers correct different types of mistakes such as tense, vocabulary, spelling, and pronoun mistakes without a clear distinction. Purnawarman (2011) explains that teachers may decide to focus on common grammatical errors made by ESL students such as articles, prepositions, and past tense verbs, and to ignore errors on adjectives, adverbs, or pronouns. The author refers to Ellis et al. (2008) who state that highly focused corrective feedback usually focuses on a single error type or category, or on a single linguistic feature such as errors in the use of prepositions; conversely, less focused corrective feedback may concentrate on more than one type of error, but correction is still restricted to a limited number of error categories, such as articles, prepositions, and past tense verbs.

\section{MATERIALS AND METHODS}

Descriptive survey design was used because it is believed to be a valid research design for researching teachers' treatment of students' oral errors (Patton, 1990). The researcher used qualitative and quantitative approaches because the combination of the two makes the finding more reliable (Creswell and Clark, 2011). Thus, to collect the primary data researcher used classroom observation and interview.

\section{Research Participants}

Shambu preparatory school was deliberately selected for the study because the researcher observed problems regarding teachers' treatment of students' oral errors during his actual teachings in the school. Besides, he knows the area well and might not face any problem of cooperation while conducting the study.

\section{Sampling Techniques}

The study population is grade eleven students and teachers of Shambu Preparatory school. Two English language teachers that teach in two grade eleven classes, one from social sciences and the other from natural sciences, were selected. Two English language teachers were purposively selected because they were the only teachers who were teaching English in grade level. The teachers were who learned English as a foreign language and consequently, their exposure to English was mostly confined to the formal learning and teaching settings.

The other sources of data were students from the selected classes. There were eleven sections of grade eleven. Eight of them were natural science classes and three of them were social science classes. Two sections: one from social sciences and the other from natural sciences were selected for the study.
Sci. Technol. Arts Res. J., Jan-March 2016, 5(1): 115-122

\section{Instruments of Data Collection}

To collect data for the study, classroom observation and interview were used. The detail is indicated below.

\section{Classroom Observation}

The researcher made classroom observation to collect data on teachers' treatment of students' English oral errors. Before filling the checklist, the researcher familiarized himself with the classes to establish a good relationship and to minimize unnatural classroom behavior that might affect the data. Thus, the first observation was done to familiarize the researcher with the classroom. During the second observation, the researcher filled the checklist which contained important points regarding the lessons.

\section{Interview}

The researcher designed seven semi-structured interview questions for the two teachers. The interview dealt with how English language teachers treat students' oral errors, the techniques they employ to treat students' oral errors and the type of oral error treatment techniques they provide students.

\section{Method of Data Analysis}

The data gathered from the target population through observation were organized and analyzed by counting the frequency of teachers' utterances and changing them into percentages whereas the data gathered through interview were thematically categorized and analyzed by using qualitative method of data analysis.

\section{RESULTS}

The results section was divided into three based on the research questions. The first section dealt with the analysis of the major types of identified students' oral errors. The second section was concerned with the types of oral error treatments EFL teachers provide students and the third one dealt with the techniques EFL teachers use to treat students' oral errors. Likewise, the discussion part dealt with the critical comparison of the current findings with the existing literature.

\section{The Major Identified Students' Oral Errors}

This section, presents the types of errors identified and the frequency of errors under each category. Sixty six errors were identified as the targeted students' English oral errors and then classified under 10 categories as Pronunciation, Tense, Verb group, Agreement, Noun group, Preposition, Word order, Article, Wrong numbers and Adjectives as shown in Table 1 below.

In Table 1 above, errors in pronunciation account for the highest frequency and percentage. Errors in pronunciation here refer to the deviation from native like utterances. This can be made clear by the following extract:

\section{Extract 1}

$\mathrm{T}$ : Would you try question no. 12 ?

S1: When salt /Sə:It/ Water Freezes, the Ice Contains Very Little Salt/Sə:I t/

T: How do you pronounce the word (the teacher spelt the word) salt?

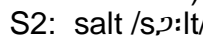

$\mathrm{T}$ : salt/s,?: It/ it is correct. 
Table 1: The Major Identified Students' English Oral Errors

\begin{tabular}{|c|c|c|c|c|c|c|c|}
\hline \multirow{2}{*}{ No } & \multirow{2}{*}{ Type of errors } & \multicolumn{2}{|c|}{ Section I } & \multicolumn{2}{|c|}{ Section II } & \multicolumn{2}{|c|}{ Total } \\
\hline & & $\mathbf{F}$ & $\%$ & $\mathbf{F}$ & $\%$ & $\mathbf{F}$ & $\%$ \\
\hline 1 & Pronunciation & 9 & 13.6 & 6 & 9.2 & 15 & 22.8 \\
\hline 2 & Tense & 9 & 13.6 & 5 & 7.8 & 14 & 21.3 \\
\hline 3 & Verb group & 1 & 1.5 & 7 & 10.6 & 8 & 12.2 \\
\hline 4 & Agreement & 3 & 4.5 & 8 & 12.2 & 11 & 16.7 \\
\hline 5 & Noun group & 3 & 4.5 & 2 & 3 & 5 & 7.5 \\
\hline 6 & Preposition & 2 & 3 & 2 & 3 & 4 & 6 \\
\hline 7 & Word order & 3 & 4.5 & - & - & 3 & 4.5 \\
\hline 8 & Article & 1 & 1.5 & 1 & 1.5 & 2 & 3 \\
\hline 9 & Wrong numbers & 1 & 1.5 & 1 & 1.5 & 2 & 3 \\
\hline 10 & Adjectives & 2 & 3 & - & - & 2 & 3 \\
\hline \multicolumn{2}{|c|}{ Total } & 34 & 51.2 & 32 & 48.8 & 66 & 100 \\
\hline
\end{tabular}

In the above extract, the first student's utterance was not correct. The student pronounced wrongly simply based on the vowel sound. He should have pronounced the word 'salt' as in 'soft'. A total of 15 (22.5\%) similar errors of pronunciation were made by the students as indicated in Table1. In the table, it was shown that the percentages of the pronunciation errors are relatively very high as compared to errors in the other categories.

The data also indicates that errors related to tenses took the second most frequent errors made by students. See the next extract.

\section{Extract 2}

T: I would have lent you my book if asked.

S: I would have asked

T: $\quad$ No, not correct. Ok Lidya?

Lidya: You had asked

$\mathrm{T}$ : Right, this is the tense in if clause of type III.

The above extract, the student made this error type because he might lack the knowledge about tense. This type of errors covered $14(21.3 \%)$ that indicates tense error is the second most frequently made by students during oral communication in EFL classes.

The third most frequently made errors were errors related to the relationship between subjects and verbs (agreement). Thus, the data shows that the other students' great problem in oral communication is a lack of knowledge in subject verb agreements. See the following extract.

\section{Extract 3}

$\mathrm{T}$ : Calories __ (measures) the energy contained in food. Chaltu: Calories measures the energy contained in food.

$\mathrm{T}$ : $\quad$ Measures or measure? Other student, Lasi? Lasi: Measure

$\mathrm{T}$ : That is measure since calories is a plural subject.

In the above extract, the student who made the error did not understand the relationship between the plural subject 'calories' and the verb 'measure'. That is why she used a singular verb for a plural subject. Next to the errors of tense, these errors of agreement and related ones were made repeatedly in the study. Table 1 shows that they covered $11(16.7 \%)$ of the total oral errors made.
The other type of errors repeatedly made by the students was errors related to verbs. These errors refer to the students' misuse (addition or omission) of verbs like to be, to do, to have or past participles. These types of errors accounted $8(12.2 \%)$ of the total oral errors made. Furthermore, the fifth most frequent types of errors identified were errors related to noun or pronoun groups. The students were heard using inappropriate or misused nouns or pronouns and addition or omission of nouns or pronouns. The following extract was observed during classroom interaction.

\section{Extract 4}

T:Ok. Number 5 ?

$\mathrm{S}$ : If there was no freedom of speech, there would not solve their problem.

$\mathrm{T}$ : Is she right?

Tola: No. It should be they would not---

$\mathrm{T}$ : good. This is correct. It is explicit pronoun to be used here.

In the above extract, the student used "there" instead of the pronoun 'they'. This led the whole sentence to be meaningless to the listener and blocked communication. These type of error occurred $5(7.5 \%)$ times from the total of 66 oral errors identified. Finally, although not so series problems like the ones mentioned above, prepositions, word order, articles, wrong numbers and adjectives were counted as errors made by the students. They covered $4(6 \%), 3(4.5 \%), 2(3 \%), 2(3 \%)$ and $2(3 \%)$ of the total oral errors made by the students respectively as shown in Table1 above.

\section{Types of EFL Teachers' Oral Error Treatments}

The other concern of the study was to investigate the types of oral errors corrective feedbacks teachers provide students during their oral interactions in EFL classes. From the data, 13 types of treatments (Provide, Transfer, Praise, Explanation, Question, Interruption, Acceptance, Repetition, Use of blackboard, Ignore, Negation, Clues and prompt and Criticism) were identified. The frequencies and percentages of the types of the treatments provided were summarized in the following table 2. 
Table 2: Types of EFL Teachers' Oral Error Treatments

\begin{tabular}{clcccccc}
\hline \multirow{2}{*}{ No. } & \multirow{2}{*}{ Types of treatments } & \multicolumn{2}{c}{ Teacher $\mathbf{1}$} & \multicolumn{2}{c}{ Teacher $\mathbf{2}$} & \multicolumn{2}{c}{ Total } \\
\cline { 3 - 8 } & & $\mathbf{F}$ & $\mathbf{\%}$ & $\mathbf{F}$ & $\mathbf{\%}$ & $\mathbf{F}$ & $\mathbf{\%}$ \\
\hline 1 & Provide & 10 & 11 & 7 & 8 & 17 & 19 \\
2 & Transfer & 7 & 8 & 7 & 8 & 14 & 16 \\
3 & Praise & 8 & 9.1 & 2 & 2.3 & 10 & 11.4 \\
4 & Explanation & 6 & 6.7 & 2 & 2.3 & 8 & 9 \\
5 & Question & 5 & 5.7 & 2 & 2.3 & 7 & 8 \\
6 & Interruption & 4 & 4.6 & 3 & 3.4 & 7 & 8 \\
7 & Acceptance & 3 & 3.4 & 2 & 2.3 & 5 & 5.7 \\
8 & Repetition & 4 & 4.6 & 1 & 1.1 & 5 & 5.7 \\
9 & Use of blackboard & 3 & 3.4 & 1 & 1.1 & 4 & 4.6 \\
10 & Ignore & 2 & 2.3 & 2 & 2.3 & 4 & 4.6 \\
11 & Negation & 2 & 2.3 & 2 & 2.3 & 4 & 4.6 \\
12 & Clues and prompt & - & - & 2 & 2.3 & 2 & 2.3 \\
13 & Criticism & - & - & 1 & 1.1 & 1 & 1.1 \\
\hline \multicolumn{2}{r}{ Total } & $\mathbf{5 4}$ & $\mathbf{6 1 . 1}$ & $\mathbf{3 4}$ & $\mathbf{3 8 . 8}$ & $\mathbf{8 8}$ & $\mathbf{1 0 0}$ \\
\hline
\end{tabular}

Table 2 indicates that different types of oral error treatments were used by the two teachers. The most frequent treatments were provide transfer and praise where $\mathrm{f}=17(19 \%), 14(16 \%)$ and $10(11.4 \%)$ respectively whereas the least treatments provided were clue and prompt, and criticism where $\mathrm{f}=2(2.3 \%)$ and $1(1.1 \%)$ respectively. However, all of them were not equally distributed between the two teachers because the teachers had their own preferences to treat the errors. It is better to give model examples of oral corrective treatments used by teachers.

\section{Provide}

This is a type of error treatment in which the teacher provides the correct answer when the student is unable to respond. For further illustration see the text below.

\section{Extract 5}

T: Who can tell me the meaning of the word "asset" written in bold in the passage?

S: Property with money value

$\mathrm{T}$ : No, property.... person

It is clear from the above extract that the student couldn't answer correctly because of his failure; the teacher provided the answer by himself. These types of error treatments by the teachers were the most frequent ones identified from the collected data. They accounted $19 \%$ of the 88 , total treatment types identified. These covered $10(11 \%)$ from $T_{1}$ and $7(8 \%)$ from $T_{2}$. To crosscheck, the data obtained from classroom observation, the responses of the interview questions about which techniques to use in the students' oral error treatment indicated that the two teachers use self correction technique as their primary technique. They responded that they give the first chance of error correction for the student who made the error. In case he/she failed to correct his/her error, teachers give the second chance to the peers or to other student in the class.

\section{Transfer}

The second most frequent type of treatments provided by EFL teachers was transfer that involves the teachers to ask other student or the class to provide the correction. These types of treatments accounted $16 \%$ of the total treatments identified in the study. For example,

\section{Extract 6}

T: Number 4. Ayantu try it.

S1: This belong to my mother

$\mathrm{T}$ : Another person? Samuel

S2: This book belongs to my brother

$\mathrm{T}$ : Right, belongs to...

In the above extract, S1 failed to give the correct response, but the teacher did not give the answer by himself rather transferred to S2. This type of error treatment was provided $7(8 \%)$ by $\mathrm{T}_{1}$ and $7(8 \%)$ by $\mathrm{T}_{2}$ as indicated in Table2.

\section{Praise}

The data indicated that praise, which involves the approval of students' answer, was the third most frequent error treatment type used by the teachers. This accounted $11.4 \%$ of the total 88 treatments counted in the study. The teachers used the strong approval of students' answer by saying 'well'. The data indicated that $8(9.1 \%)$ of this method was used by $T_{1}$ and $2(2.3 \%)$ by $T_{2}$. Here the teachers overused praise. In the same case they used strong praise for very weak and incorrect students' responses. This may have its negative consequences on the students' performances. It may develop over confidence among the students which in turn leads to generalization of incorrect utterances as the correct ones.

\section{Explanation}

Explanation refers to giving explanation for students' errors. From 13 types of identified oral errors, 8(9.1\%) of the total treatment types shown in Table2 above was explanation. The extracts bellow shows that the teacher has given brief explanation about the relationship between subject and verb. It was this kind of error treatment used frequently next to praise. The distribution of this types of treatments between the two teachers shows that $6(6.7 \%)$ and 2(2.3\%)were used by $T_{1}$ and $T_{2}$ respectively.

\section{Extract 7}

$\mathrm{T}$ : The clouds__ (grows) colder

S: The clouds grows colder.

T: We use the verb grow because the subject is plural.

\section{Question and Interruption}

Question refers to numerous ways of asking for new response often with clues. Interruption is a type of error 


\section{Leta Regasa and Tamiru Olana}

treatment in which the teacher provides the learner incorrect utterance usually following the error or before the student has completed what he/she is trying. Each of these error treatments covered equally $7(8 \%)$ of the total identified errors (Table2). The data from interview regarding the time to correct students' oral errors in EFL classes, two of the sampled teachers responded that they didn't interrupt their students in the middle of their utterances rather they wait patiently until the finish their utterances. They responded that because the students would be discouraged if treated in this way. The data gathered from observation indicated that teachers use interruption and question as the fifth most frequent types of error treatment.

\section{Repetition and Acceptance}

Repetition refers to repeating students' utterances with intent to have student correct his/her oral error by him/herself. Acceptance shows the approval of students' oral errors. They shared $5(5.7 \%)$ percentage each of the total treatments made by the teachers. Repetition covered $4(4.6 \%)$ by $\mathrm{T}_{1}$ and $1(1.1 \%)$ by $\mathrm{T}_{2}$ whereas acceptance covered $3(3.4 \%)$ by $\mathrm{T}_{1}$ and $2(2.3 \%)$ by $\mathrm{T}_{2}$. These indicate that both types of treatments of oral errors occurred in equal frequency as shown in the Table 2 above.

\section{Negation, Ignore and Use of Blackboard}

The results also showed that negation and ignore and use of blackboard shared similar percentages 4(4.6\%) each of the total error treatments made by teachers. Negation refers to the rejection of part or all of the students' utterances; in ignore, teachers go to other topics. The data also showed that the teachers'
Sci. Technol. Arts Res. J., Jan-March 2016, 5(1): 115-122

treatments were supported by the use of the blackboard. The teachers' responses on the interview also indicated that they inform the students' errors by writing the parts of their utterances with errors on the blackboard. Teachers also revealed that they use other methods of treatments like asking questions and giving clues. The classroom observation results also indicated that negation, ignore and blackboard usage were the least frequent types of treatments used by the teachers.

\section{Criticism}

According to the data organized in Table2, the least frequently used type of treatments by teachers was criticism. The teachers used only $1(1.1 \%)$ of the total treatments used. This shows that teachers do not focus on criticizing their students for their errors. As this kind of error treatment is not pedagogically encouraged, teachers are encouraged not to use it permanently.

Generally, provide, transfer, praise, explanation, interruption and question were the first six treatment types most frequently employed by the teachers. The others ranged from repetition to criticisms were used by the teachers least frequently.

\section{Techniques EFL Teachers Use to Treat Students' Oral Errors}

The other research question was to investigate the techniques teachers use to correct students' English oral utterances. To identify the techniques, the errors identified were grouped into teacher treated and student treated errors as summarized in Table 3 below.

Table 3: The Techniques EFL Teachers Use to Treat Students' Oral Errors

\begin{tabular}{|c|c|c|c|c|c|c|c|c|c|c|c|}
\hline Categories & Pronunciation & Tense & Agreement & Preposition & Word order & Articles & $\begin{array}{c}\text { Wrong } \\
\text { number }\end{array}$ & Adjectives & $\begin{array}{l}\text { Verb } \\
\text { group }\end{array}$ & $\begin{array}{l}\text { Noun } \\
\text { group }\end{array}$ & Total \\
\hline $\begin{array}{l}\text { Errors Treated } \\
\text { by }\end{array}$ & 10 & 9 & 6 & 2 & 1 & 2 & 2 & 1 & 7 & 4 & 44 \\
\hline Teachers & 6 & 7 & 4 & 2 & 1 & 1 & 1 & & 7 & 1 & 33 \\
\hline Self & 2 & & 1 & & & 1 & & 1 & & & 5 \\
\hline Peer & 2 & 2 & 1 & & & & 1 & & & & 6 \\
\hline
\end{tabular}

In Table 3 above, from the 44 treated errors, 33 of them were treated by teachers whereas 5 of them were treated by an individual student and 6 of them were treated by peer groups or other students. Next to the teachers, the peer group took considerable number of oral errors' treatment and the least number of errors were treated by the students themselves.

The interview data indicates that all respondent teachers used students' self correction as a primary technique. It also shows that they give the first chance of error correction to a student who made the error. In case the student fails to correct his/her oral error, teachers give the second chance to peer groups or other students to correct the oral errors and when these techniques fail to be operational, they give correction by themselves. However, the observation data organized in Table 3 above disproved what the teachers said they do as out of 44 oral errors treated in the classrooms, only 11 of them were treated by students.

It is also worthwhile to identify the treated and untreated oral errors amongst the totally identified oral errors. See table below for the detail.

Table 4: Treated and untreated English oral errors

\begin{tabular}{|c|c|c|c|c|c|c|c|c|c|c|c|}
\hline Category & pronunciation & tense & agreement & preposition & $\begin{array}{l}\text { Word } \\
\text { order }\end{array}$ & Articles & $\begin{array}{l}\text { Wrong } \\
\text { number }\end{array}$ & adjectives & $\begin{array}{l}\text { Verb } \\
\text { group }\end{array}$ & $\begin{array}{l}\text { Noun } \\
\text { group }\end{array}$ & Total \\
\hline $\begin{array}{l}\text { Number } \\
\text { of Errors }\end{array}$ & 15 & 14 & 11 & 4 & 3 & 2 & 2 & 2 & 8 & 5 & 66 \\
\hline $\begin{array}{l}\text { Treated } \\
\text { Errors }\end{array}$ & 10 & 9 & 6 & 2 & 1 & 2 & 2 & 1 & 7 & 4 & 44 \\
\hline $\begin{array}{l}\text { Untreated } \\
\text { Errors }\end{array}$ & 5 & 5 & 5 & 2 & 2 & & & 1 & 1 & 1 & 22 \\
\hline
\end{tabular}




\section{Leta Regasa and Tamiru Olana}

The 66 oral errors made by the students were categorized as treated and untreated errors. From the total errors, 44 were treated and 22 were not treated. In the interview, the teachers responded that they treat students' oral errors selectively which was also confirmed by the observation data (22 errors untreated). This is also pedagogically supported that it may not be necessary to correct each and every error that appears in students' utterances in EFL classes.

\section{DISCUSSION}

It was necessary to validate the findings by relating them with the existing literature. Accordingly, the most frequently made oral errors by students were summarized in Table 1 as pronunciation, tense, verb group, agreement, noun group, preposition, word order, article, wrong numbers and adjectives from pronunciation, the most frequent, to article, wrong word and adjectives, the least frequent. The frequent occurrence of pronunciation errors by students, among other things, exactly matches with Tamiru and Zeleke's (2015) study, which was conducted on teachers' productive skills errors. The result showed that most of the oral errors made by teachers were pronunciation errors. Even though the objective of this study was not to compare this research with the previous one, students' making high frequency pronunciation errors in the current research context is not surprising. However, it might worry us who would correct the errors as teachers are not better than their students.

It is obvious that errors are natural, however, what matters is the ways teachers treat them. The results depicted that teachers provide different types of oral errors treatment depending on the frequency of errors not depending on each types of errors. In line with this Allwright and Bailey (1991) argue that errors should be treated on the basis of their occurrence in classroom interaction. Therefore, errors of high frequency should be given more attention and emphasis than errors of low frequency. Thus, according to the findings, students need more oral error treatments in provide, and transfer than in praise and explanation putting criticism a category which needs the least position.

The results indicated that the targeted teachers use different techniques to treat students' oral errors. In Table 3 , for example, three fourth of the errors were treated by teachers but only one fourth of them were treated by students. That means, the chance given for the involvement of students in correcting their oral errors was under the influence of teachers correction. However, the modern language teaching theory encourages the importance of treating oral errors by students (self correction) and this idea has a great support from (Edge, 1989).

The data also indicated that teachers, most of the time, use teacher feedback as a technique by ignoring its importance. In connection to this Damon and Phelps (1989) convincingly argue that learners use of sources of information and interactions for each other in such a way that they take on the responsibilities in commenting on each other's work can contribute to peers' social relations, intellectual improvement, and progressing of creative and critical thinking. Therefore, teachers have to be aware that they are not the only sources of feedback; students can also provide feedback to each other. Mittan (1989), Damon and Phelps (1989) also claim that peer feedback
Sci. Technol. Arts Res. J., Jan-March 2016, 5(1): 115-122

has an advantage in providing cognitive benefit in leading students to think rather than receive feedback from the teacher. Otherwise, students who get feedback only from their teacher see the teacher as a judge who critiques what they work.

The data also depicts that teachers do not give attention to correct some oral errors of their students. For example, from the total errors made by the students, the teachers treated two third of them and ignored one third. In the interview responses, the teachers also reported that they treat students' oral errors selectively which was also confirmed by the observation data. This is pedagogically supported because it may not be necessary to correct each and every error that appears in students' utterances in EFL classes. In line with this, Makiano (1993) claims that correcting every error may hinder learning in different ways and the teachers should use effective strategies based on the purpose of language learning. Purnawarman (2011) also agrees that teachers may decide to focus on common grammatical errors such as articles, prepositions, and past tense verbs, and to ignore errors on adjectives, adverbs, or pronouns made by students by referring Ellis et al. (2008) who state that highly focused corrective feedback usually focuses on a single error type or category, or on a single linguistic feature such as errors in the use of prepositions. Conversely, less focused corrective feedback may concentrate on more than one type of error, but correction is still restricted to a limited number of error categories, such as articles, prepositions, and past tense verbs.

\section{CONCLUSIONS}

So far the results of the study revealed that Shambu Preparatory School EFL teachers treat their students' linguistic problems that occur in different degrees and categories. For example, the most frequent errors they made were errors of pronunciation, tense, agreement, verb group and noun group. In all these cases, teachers were seen providing the oral errors by themselves in contrary to the pedagogy. However, in this study, the case is different as $44 / 66$ oral errors were treated by teachers and only $11 / 66$ errors were treated by students. Therefore, EFL teachers' error treatment in the school is very critical.

Making oral errors in EFL classes is one way of learning in which students learn from their errors and improve their language proficiency. Therefore, EFL teachers have to use different techniques and strategies to treat these errors and enhance the language development of students. Moreover, correcting every error may hinder learning in different ways and teachers need use effective strategies based on the purpose of language learning.

Based on the conclusions drawn, the researcher would like to forward the points to be taken into consideration.

- English language teachers need to identify the effective ways in which students' oral errors are treated to enhance their oral communication.

- Error treatment types like negation and criticism which make students unwilling to speak need to be avoided and techniques that facilitate students' learning of the language should be selectively used. 


\section{Leta Regasa and Tamiru Olana}

- Over correction of students errors results in intimidation, impressments, frustration and anxiety. Non correction makes the students think that the teacher is incompetent and careless. In addition, absence of error correction may hinder students' achievement on the accuracy of the language. Therefore, teachers are advised to keep the balance.

- Teachers are recommended to be able to create a friendly, stress free, sensitive, save and supportive environment, that is conductive for learning, where errors are perceived as a natural occurrence in the process of foreign language learning.

\section{Conflict of Interest}

None declared.

\section{REFERENCES}

Allwright D. and K. Bailey (1991). Focus on the language introduction to classroom research for language teachers. Cambridge, Cambridge University press.

Ancker, W. (2000). Errors and corrective feedbacks: updated theory and classroom practice. English Teaching Forum, $8(4), 20-25$.

Brown, D. (1994). Principles of language learning and teaching. New York: London.

Brown, D. (2000). Principles of language learning and teaching. New York: Longman.

Chaudron, C. (1986). Teachers' priorities in correcting students' errors: in R. Day (Ed.). Learning to talk: conversation in second language acquisition, Rowley, Mass: Newbury House.

Chaudron, C. (1988). Second language classroom, research on teaching and learning. Cambridge: Cambridge University press.

Corder, S. P. (1981). Error analysis and inter language. London: oxford University press.

Corder, S. P. (1974). "The significance of students' errors" in J. C Richards (Ed.), Error Analysis: Perspective on Second Language Acquisition. London: Longman.

Creswell, J.W. and Clark, V.L. (2011).Designing and conducting mixed Method research (2nd ed.) Thousand Oaks, CA: Sage.

Damon, W. and Phelps, E. (1989). Strategic uses of peer learning in children's education. In Ladd, G.W., and Berndt T. J. (Eds.), Peer relationship in child development (pp. 135-156). USA: John Wiley and Sons.

Edge, J. (1989). Mistakes and correction. London: Longman.

Ellis, R. (2008). A typology of written corrective feedback types. ELT Journal, 63(2): 97-107.

Ferris, D. (2002). Responding to Students Error: Issues and Strategies: The University of Michigan Press.

George, H.V (1972). Common errors in learning English. Rowley: Newberry House.
Sci. Technol. Arts Res. J., Jan-March 2016, 5(1): 115-122

Hattie, J. and Gan, M. (2011). Instruction based on feedback. In R. Mayer and P. Alexander (Eds.), Handbook of research on learning and instruction, pp. 249-27. New York: Routledge.

Hendrickson, J. M. (1980). The treatment of error in written work. Modem Language Journal, 64, 216-221.

Hilton, H. (2007). Review of Expertise in second language learning and teaching by Johnson, K. (Ed.). System, 35, 112-117.

Leki, I. (1990). Potential problems with peer responding in ESL writing classroom. CATESOL Journal, 3, 5-17.

Makiano, T. (1993). "Learner self correction in EFL written composition", ELT Journal 47(4): 337-441.

Mittan, R. (1989). The peer review process: Harnessing students' communicative power. In D. M. Johnson and D. $\mathrm{H}$. Roen (Eds.), Richness in writing: Empowering ESL students (pp. 207-219). White Plains: NY: Longman

Nuru Mohammed (2000). "Feedback in the EFL classroom: An exploration of its role in communication of teacher expectation" unpublished Ph. D Thesis, AAU.

Patton, M. Q. (1990). Qualitative evaluation and research methods. London: Sage.

Purnawarman, P. (2011). Impact of Teacher Feedback on ESL/EFL Students' Writing. Virginia Polytechnic Institute and State University. PhD Disseration. Retrieved from: https:// theses.lib.vt.edu/theses/available/etd-12122011211734/unrestricted/Purnawarman_P__ Dissertation_ 2011.pdf accessed on 28 October $\overline{2} 0 \overline{15}$.

Sileshi Abdisa (2008). ETL teachers' corrective feedback on oral errors: Metu Teachers' Training College in Focus. "Unpublished M. A Thesis, AAU.

Stern, H.H. (1992). Issues and options in language teaching. Oxford: Oxford University press.

Tamiru Olana and Zeleke Teshome (2015). EFL Teachers' Productive Skills Errors and Their Effects on Students' English Language Proficiency: The Case of Selected Preparatory Schools in East Wollega Zone. Science, Technology and Arts Research Journal, 4(4): 164-173.

Teshome Imana (1995). "Teachers' corrective treatment of grade 11 oral errors." Unpublished M. A Thesis, AAU.

Vanlier, L. (1995). Introduce language awareness. Penguin books Ltd. London.

Wondwossen Tamirat (1992). Classroom Feedback Behaviors of Grade Eleven English Teachers. Unpublished MA Thesis: Addis Ababa University.

Yang, M., Badger, R. and Yu, Z. (2006). A comparative study of peer and teacher feedback in a Chinese EFL writing class. Journal of Second Language Writing, 15(3): 179200. 